standard of $0.5 \mathrm{lb}$. protein equivalent per $10 \mathrm{lb}$. of milk of average quality as a safo standard for farm practice.

Prof. R. G. Baskett, in a paper dealing with the firmness of fat in bacon pigs, stated that the back fat of pigs receiving de-germed maizo meal had a significantly lower iodine value than that of pigs receiving half their ration in the form of maize meal.

Mr. H. Trefor Jones, in a paper on smoke pollution, said that in a town the size of Leeds domestic chimneys alone contribute to the atmosphere tho equivalent of nearly a ton of sulphuric acid per acro per annum : in the industrial districts of the West Riding of Yorlsshire, however, the sulphurous fumes are contributed chiefly by industrial chimneys and smouldering pit heaps. Most of the damage to crops is dono during the dormant season: winter-sown crops like wheat and winter vegetables are the chief sufferers, whilst it is unsafe to spray potatoes with copper preparations even under conditions of mild pollution. In confirming or disproving cases of alleged smoko damago, and in explaining differences in productivity of the various parts of affected fields, the estimation of the sulphate content in the soil had proved very useful. Sulphate figures in excess of 0.020 per cent for grassland, and 0.030 per cent for arable land indicate smoke pollution.

Prof. S. P. Mercer had a good word to say for Yorkshire fog grass under certain conditions in
Northern Ireland, advocated shorter leys combined with August sowing, and stated that rushes could be very largely controlled by two cuttings a year for two successivo seasons. Dr. A. E. Muskett described a laboratory method which allows seed disinfectants to be tested for efficiency in ten days at any time of the year. Radiation for 20 minutes with a quartz mercury vapour lamp is used to promote sporulation of the fungus, thus making easier the examination of the seeds at the end of the test. Dr. J. Carroll stated that until recently eelworms had not been a serious pest in Eire, but that root eelworm of potatoes was spreading and that the bulb strain of Anguillulina dipsaci was beginning to attack onions, a crop which during the last few years had undergone a remarkable increase in Eire. Mir. R. Chamberlain described the extraordinary but successful measures adopted in Northern Ireland to stamp out the chrysanthemum midge, measures which included the scheduling of an area within which no living chrysanthemum plant could bo kept, and the intensive inspection of all premises in the area.

Other papers read at the meeting included contributions on aspects of education by Mr. S. J. Wright and Mr. J. Getty: a paper on tho flax-growing industry, by Mr. WV. J. Megaw, peat land reclamation, by Mr. J. C. Baird, and a general account of the agriculture of Northern Ireland by Mr. J. Morrison.

\title{
UNION BETWEEN HOST AND PARASITE IN HIGHER PLANTS
}

$\mathrm{O}^{\mathrm{N}}$ this subject, Schumacher and Halbsguth have recently published an interesting and sugges. tive paper ${ }^{1}$. Their observations aro based on extensivo studies of species of Cuscuta and Orobanche on a wide range of host plants; with the union of Cuscuta and its host, particularly, thoy havo mado uso of techniques which permit the recognition of protoplasmic connexions, usually freezing thomaterial, cutting on the sliding microtomo and then transferring immediately to iodine potassium-iodido solution. Afterwards the walls were swollen and tho connexions stained by a modification of Moyer's pyoctannin method.

In all cases they find (contrary to somo earlier observations of Mrs. Thoday ${ }^{2}$ ) no direct connexion botween tho sieve-tubes of host and parasite; the sieve-tubes of the parasite, indeed, are not found differentiated in the closo neighbourhood of the point of union in tho haustorium. From tho haustorium, in Cuscuta, hypha-liko cells ramify from tho parasito penetrating tho phloem tissue; where these cells end in the neighbourhood of a sieve-tubo thoy may develop a comb.like expansion of which the teeth close on the sieve-tube, so that these cells make very good contact with tho siove-tube, of which the wall is often much compressed. In tho walls of theso hyphæ, which aro rich in protoplasm and often multinucleate, very numerous plasmodesma-like structures are found which seem to end freo on their surface, but these 'plasmodesma' are nover found on tho comb. liko ends, which seem definitely constructed to facilitato exchange between host sieve-tube and parasito.

In Orobanche theso hypha-like cells aro usually replaced by a densely plasmatic tissue, with prominent, usually single, nuclei ; theso cells multiply rapidly, they surround and compress and finally obliterate many of the sievo-tubes; but tho sieve-tube up to the point of obliteration remains full of contents and presumably continues to transfer material from host to this secretory type of haustorial tissue.

Tho authors concludo that their observations suggest that the transfer of food from host to parasite must take placo across tho walls of contiguous cells, the permeability of host sieve-tubo presumably increasing, whilst the absorptive properties of the haustorial secretory tissues may also be accentuated at the point of union. The distribution of the proto. plasmic connexions suggests that food transfer is not their role. It is argued they may help the invading haustorial cells to orientate themselves in the host and, in accordance with such perceptive functions, the authors record the presence of similar structures in the outer wall of epidermal cells, notably of tendrils. But their figures suggest that theso structures aro rather large for typical protoplasmic connexions and it must bo Ieft for further work to clear up the possible correlation of these epidermal features with plasmodesma or, on the other hand, with the waxsecreting channels described by Dous and Ziegenspeck $^{3}$. These vertical wax-secreting channels also deservo further scrutiny in view of Madeleine Mroyer's observations that the wax distribution suggests its movement along horizontal channels in the cutinized layers of tho outer wall.

\footnotetext{
I Jahrb. viss. Bot., 87 (2/3), 324-355 (1938).

Ann. Bot. (1911)

Bot. Archiv., 19 (1927); 29 (1928).

- Protoplasma, 29 (1938).
} 